AL-амилоидоз с преимущественным поражением сердца. Алгоритм неинвазивной диагностики \title{
амилоидной кардиомиопатии
}

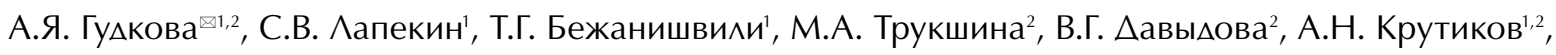 \\ А.Н. Куликов ${ }^{1,3}$, А.А. Стрельцова², С.Е. Андреева', Р.В. Грозов², А.А. Полякова',2, А.А. Костарева², \\ Г.Н. Салогуб $\sigma^{1,2}$, Е.В. ШАяхто ${ }^{1,2}$ \\ 'ФГБОУ ВО «Первый Санкт-Петербургский государственный медицинский университет им. акаА. И.П. Павлова» Минздрава России, \\ Санкт-Петербург, Россия; \\ 2ФГБУ «Национальный медицинский исследовательский центр им. В.А. А^мазова» Минздрава России, Санкт-Петербург, Россия; \\ ${ }^{3}$ ФГБВОУ ВО «Военно-медицинская акацемия им. С.М. Кирова» Минобороны России, Санкт-Петербург, Россия
}

\begin{abstract}
Аннотация
Приводятся сведения хитературы и описание клинического течения заболевания при изолированном/преимушественном поражении сердша ами^оихозом. Амилоидная кардиомиопатия яв^яется самой распространенной фенокопией гипертрофической кардиомиопатии.

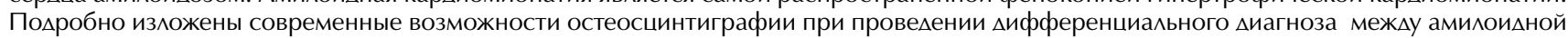
кардиомиопатией, вызванной AL-амилоидозом, и транстиретиновым ами^оидозом.
\end{abstract}

Ключевые слова: $\mathrm{AL}$-амилоидОз, феенокопии гипертрофической кардиомиопатии, остеосцинтиграфрия

имя шитирования: Гудкова А.Я., Аапекин С.В., Бежанишвили Т.Г., Трукшина М.А., Аавыдова В.Г., Крутиков А.Н., Куликов А.Н., Стрельцова А.А., Андреева С.Е., Грозов Р.В., Полякова А.А., Костарева А.А., Салогуб Г.Н., Шляхто Е.В. АL-амилойоз С преимушественным поражением сердца. А^горитм неинвазивной диагностики амилоицной кардиомиопатии. Терапевтический архив. $2021 ; 93$ (4): 487-496. DOI: $10.26442 / 00403660.2021 .04 .200689$

REVIEW

\section{AL-amyloidosis with cardiac involvement. Diagnostic capabilities of non-invasive methods}

Alexandra Ya. Gudkova ${ }^{\otimes 1,2}$, Sergei V. Lapekin', Tinatin G. Bezhanishvili', Maria A. Trukshina², Victoria G. Davydova², Aleksandr N. Krutikov',2, Aleksandr N. Kulikov',3, Anna A. Streltsova', Sofiia E. Andreeva', Roman V. Grozov', Anzhelika A. Poliakova ${ }^{1,2}$, Anna A. Kostareva ${ }^{2}$, Galina N. Salogub ${ }^{1,2}$, Evgenii V. Shlyakhto',2

'Pavlov First Saint Petersburg State Medical University, Saint Petersburg, Russia;

${ }^{2}$ Almazov National Medical Research Center, Saint Petersburg, Russia;

${ }^{3}$ Kirov Military Medical Academy, Saint Petersburg, Russia

\section{Abstract}

There are presented the literature data and a description of the clinical course of the disease in isolated/predominant cardiac amyloidosis. Amyloid cardiomyopathy is the most common phenocopy of hypertrophic cardiomyopathy. The modern possibilities of non-invasive diagnostics using osteoscintigraphy for the differential diagnosis between amyloid cardiomyopathy caused by AL- and transthyretin amyloidosis are described in detail.

Keywords: AL-amyloidosis, hypertrophic cardiomyopathy phenocopies, bone scintigraphy

For citation: Gudkova AYa, Lapekin SV, Bezhanishvili TG, Trukshina MA, Davydova VG, Krutikov AN, Kulikov AN, Streltsova AA, Andreeva SE, Grozov RV, Poliakova AA, Kostareva AA, Salogub GN, Shlyakhto EV. AL-amyloidosis with cardiac involvement. Diagnostic capabilities of noninvasive methods. Terapevticheskii Arkhiv (Ter. Arkh.). 2021; 93 (4): 487-496. DOI: 10.26442/00403660.2021.04.200689

\footnotetext{
Информация об авторах / Information about the authors

Фудкова Александра Яковлевна НИИ серАечно-сосудистых заболеваний НКИЦ, проф. кафр. фракультетской терапии ФГБОУ ВО «ПСПбГМУ им. акаА. И.П. Павлова», веА. науч. сотр. Института молекулярной биологии и генетики ФГБУ «НМИЦ им. В.А. Алмазова». Тел.: +7(911)904-77-28;

e-mail: alexagood-1954@mail.ru; ORCID: 0000-0003-0156-8821

Аапекин Сергей Вмахимирович - врач высшей категории отА-ния раАиологии ФГБОУ ВО «ПСПбГМУ им. акаА. И.П. Павлова». ORCID: 0000-0003-4437-6969

Бежанишвими Тинатин Гелаевна - м^. науч. сотр. лаб. кардиомиопатий НИИ сердечно-сосудистых заболеваний НКИЦ, ассистент каф. факультетской терапии ФГБОУ ВО «ПСПбГМУ им. акаА. И.П. Пав^ова». ORCID: 0000-0002-3167-6340

Трукшина Мария Александровна - вед. науч. сотр. НИО сердечной неАОстаточности ФГБУ «НМИЦ им. В.А. Аммазова». ORCID: 0000-0003-3597-6794
}

Аавыцова Виктория Германовна - аспирант ФГБУ «НМИЦ им. В.А. Алмазова». ORCID: 0000-0002-0233-5555
${ }^{\square}$ Alexandra Ya. Gudkova. E-mail: alexagood-1954@mail.ru; ORCID: 0000-0003-0156-8821

Sergei V. Lapekin. ORCID: 0000-0003-4437-6969

Tinatin G. Bezhanishvili. ORCID: 0000-0002-3167-6340

Maria A. Trukshina. ORCID: 0000-0003-3597-6794

Victoria G. Davydova. ORCID: 0000-0002-0233-5555 
К амилоидозу сердца приводит гетерогенная группа заболеваний, характеризующихся структурно-функциональными нарушениями сердца вследствие отложения во внеклеточном матриксе аномального фибриллярного белка (амилоида). К амилоидным кардиомиопатиям (фенокопиям гипертрофической кардиомиопатии - ГКМП) наиболее часто приводят $\mathrm{AL}-$-амилоидоз, а также наследственные и ненаследственные формы транстиретинового амилоидоза $[1,2]$. Самой распространенной формой системного амилоидоза на протяжении приходится около 67-68\% всех случаев [1]. AL-амилоидоз встречается с частотой от 5 до 12 человек на 1 млн в год [3].

Поражение сердца при AL-амилоидозе варьируется от 50 до 90\% случаев [4, 5] и, как правило, приводит к прогрессированию хронической сердечной недостаточности $(\mathrm{XCH})$. Чем ярче и многочисленнее внесердечные проявления и лабораторные признаки плазмоклеточной дискразии при AL-амилоидозе, тем короче путь к диагнозу $[4,5]$. Наибольшие трудности диагностики до сегодняшнего дня возникают при «изолированном/преимущественном» поражении сердца при AL-амилоидозе, которое встречается у $5 \%$ больных $[1,6]$.

Приводим описание клинического случая.

Пациент - мужчина 59 лет.

История заболевания. Более 20 лет - анамнез гипертонической болезни, корригируемой, с редкими подъемами артериального давления (АД) до 170/90 мм рт. ст. (макмногих десятилетий является AL-амилоидоз, на долю которого

симальное), «рабочее» 130/80 мм рт. ст. В последний год отметил уменьшение потребности в гипотензивной терапии для достижения целевых значений АД. На фоне настоящего ухудшения наблюдается нормотония, без гипотензивной терапии.

Ранее в течение 3 лет наблюдались редкие приступы давящих болей за грудиной при физической нагрузке $(\Phi Н)$, самостоятельно купирующиеся в покое. В июне 2018 г. больной госпитализирован в связи с клиникой острого коронарного синдрома (ОКС).

На коронароангиографии (КАГ) выявлен стеноз передней межжелудочковой артерии (ПМЖА) 80\% и огибающей артерии (ОА) 70\%. Выполнено стентирование ОА (1DES), ПМЖА (1BMS). На контрольной КАГ: области стентирования без признаков диссекций и тромбоза, кровоток по ОА и ветвям удовлетворительный, кровоток по ПМЖА, а также ее ветвям удовлетворительный.

На фоне терапии состояние пациента стабилизировалось. Через 3-4 мес (сентябрь 2018 г.) - повторное ухудшение: появление и прогрессирование одышки, быстрое снижение толерантности к ФН, эпизоды удушья в ночное время, отеки нижних конечностей.

Больной направлен на консультацию в ФГБОУ ВО «ПСПбГМУ им. акад. И.П. Павлова».

Жалобь:

• одышка при минимальной ФН;

• редкие приступы давящих болей за грудиной при ФН, самостоятельно купирующиеся в покое;

Крутиков Александр Николаевич - к.м.Н., вед. науч. сотр. НИО инфильтративных заболеваний сердца Института молекулярной биологии и генетики ФГБУ «НМИЦ им. В.А. А^мазова», м.н.с. ^аб. кардиомиопатий НИИ сердечно-сосудистых заболеваний НКИЦ ФГБОУ ВО «ПСПбГМУ им. акаА. И.П. Пав^ова».

ORCID: 0000-0001-6897-6171

Куликов Александр Николаевич - А.М.Н., рук. ОтА. кАинической физиологии и функциональной Аиагностики, зам. глав. врача по медишинской части (по терапии) ФГБОУ ВО «ПСПбГМУ им. акаА. И.П. Павлова», проф. каф. пропедевтики внутренних болезней ФГБВОУ ВО «ВМА им. С.М. Кирова».

ORCID: 0000-0002-4544-2967

Стрельцова Анна Алексеевна - врач ультразвуковой диагностики ФГБУ «НМИЦ им. В.А. А^мазова». ORCID: 0000-0002-2766-8946

Аниреева София Евгеньевна - студент лечебного фрак-та ФГБОУ ВО «ПСПбГМУ им. акаА. И.П. Павлова».

ORCID: 0000-0001-7306-9525

Грозов Роман Викторович - К.м.Н., врач-патологоанатом, зав. патоАогоанатомическим отА. АРК №1 ФГБУ «НМИЦ им. В.А. А^мазова». ORCID: 0000-0001-8016-7692

Полякова Анжелика Александровна - к.м.н., врач-кардиолог, м.н.с. маб. кардиомиопатий НИИ сердечно-сосудистых заболеваний НКИЦ, ассистент каф. фракультетской терапии ФГБОУ ВО «ПСПбГМУ им. акаА. И.П. Пав^ова».

ORCID: 0000-0002-6655-5274

Костарева Анна Александровна - К.м.н., дир. Института молекумярной биологии и генетики ФГБУ «НМИЦ им. В.А. Алмазова». ORCID: 0000-0002-9349-6257

Салогуб Галина Николаевна - К.м.н., АОц. каф. фракультетской терапии ФГБОУ ВО «ПСПбГМУ им. акаА. И.П. ПавАова», зав. каф. внутренних болезней Института медицинского образования ФГБУ «НМИЦ им. В.А. Аммазова». ORCID: 0000-0001-8951-1680

ШАяхто Евгений Влахимирович - акаА. РАН, засл. Аеят. науки РФ, ген. Аир. ФГБУ «НМИЦ им. В.А. Алмазова», Презилент Российского кардиологического общества, гл. кардиолог Санкт-Петербурга и Северо-Запалного фелерального округа, зав. кафр. фракультетской терапии ФГБОУ ВО «ПСПбГМУ им. акаА. И.П. Пав^ова». ORCID: 0000-0003-2929-0980
Aleksandr N. Krutikov. ORCID: 0000-0001-6897-6171

Aleksandr N. Kulikov. ORCID: 0000-0002-4544-2967

Anna A. Streltsova. ORCID: 0000-0002-2766-8946

Sofiia E. Andreeva. ORCID: 0000-0001-7306-9525

Roman V. Grozov. ORCID: 0000-0001-8016-7692

Anzhelika A. Poliakova. ORCID: 0000-0002-6655-5274

Anna A. Kostareva. ORCID: 0000-0002-9349-6257

Galina N. Salogub. ORCID: 0000-0001-8951-1680

Evgenii V. Shlyakhto. ORCID: 0000-0003-2929-0980 


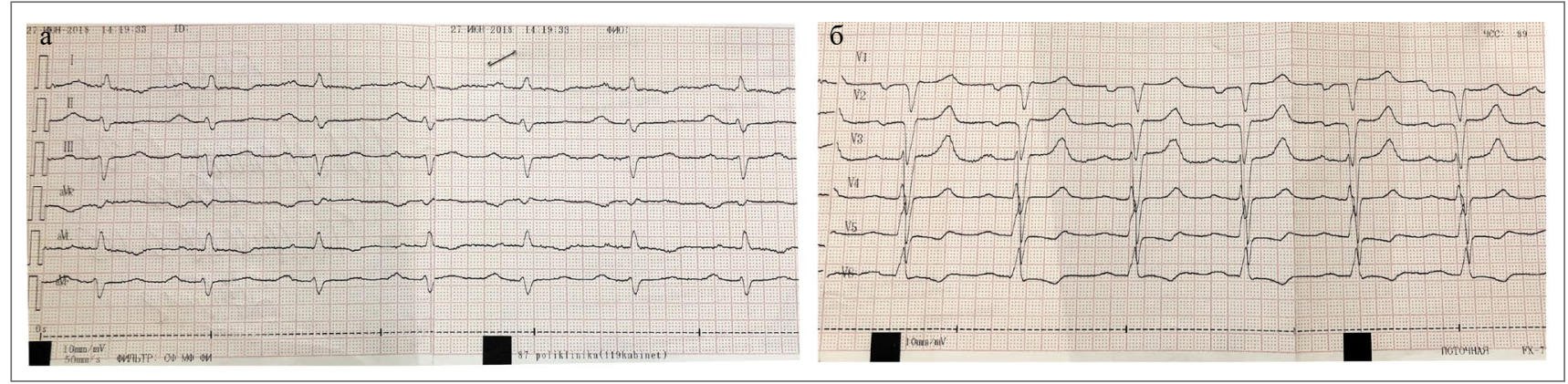

Рис. 1. ЭКГ больного 60 мет с AL-амимоидозом с преимущественным поражением сердца, ^ямбда-вариант.

Таблица 1. Аинамика ЭхоКГ-показателей за период наблюдения

\begin{tabular}{lccc}
\hline Показатели & $\mathbf{2 9 . 0 6 . 2 0 1 8}$ & $\mathbf{1 0 . 0 8 . 2 0 1 8}$ & $\mathbf{1 7 . 1 1 . 2 0 1 8}$ \\
\hline Толщина МЖП, мм & 24 & 24 & 24 \\
Толщина ЗСЛЖ, мм & 18 & 18 & 24 \\
КДР ЛЖ, мм & 51 & 49 & 49 \\
Индекс КДР ЛЖ, мм/м & 24,4 & 60 \\
ЛП, мм & 25,4 N 2,2-3,0) & 56 & $54 \times 52$ \\
ПП, мм & 56 & $43 \times 52$ & 63 \\
Индекс ПП, мл & $55 \times 51$ & 63 & 47 \\
ПЖ, мм & 60 & 45 & 11 \\
ПСПЖ, мм & 43 (N до 40) & 10 & 298 \\
Индекс массы миокарда ЛЖ, г/м² & 4 & 289 & 28 \\
ФВ, \% & 261 & 33 & 57 \\
СДЛА, мм рт. ст. & 47 & 55 & Диффузная гипокинезия \\
Кинетика миокарда ЛЖ & 44 & Рестриктивный тип \\
Диастолическая дисфункция & Рестриктивный тип & Рестриктивный тип & наполнения ЛЖ \\
Жидкость в полости перикарда & наполнения ЛЖ & наполнения ЛЖ & Небьшольшое количество \\
\hline Примечание. КДР - конечно-диастолический размер, СДЛА -сердечное давление в легочной артерии. & Небольшое количество
\end{tabular}

Примечание. КДР - конечно-диастолический размер, СДЛА - сердечное давление в легочной артерии.

- общая слабость, потеря массы тела (3 кг) при сохраненном аппетите.

Объективно. Состояние относительно удовлетворительное. Нормотония (АД 120 и 80 мм рт. ст.), при переходе из вертикального положения в горизонтальное (на 1-й минуте 110/80, на 3-й минуте 105/75), пульс ритмичный, симметричный, удовлетворительного наполнения, 78 уд/мин. Проявления сердечной недостаточности (легкий цианоз губ, дыхание жесткое, гипостатические влажные храпы в нижних отделах обоих легких. Печень выступает из-под края реберной дуги на 2 см. Легкая пастозность стоп).

Выполнено (электрокардиография - ЭКГ, суточное мониторирование ЭКГ, трансторакальная эхокардиография - ЭхоКГ)

ЭКГ: ритм синусовый, правильный. Низковольтажный характер ЭКГ (без динамики по сравнению с 06.2018). Признаки блокады передневерхнего разветвления левой ножки пучка Гиса. Атриовентрикулярная (AB)-проводимость на верхней границе нормы.

Признаки увеличения левого (ЛП) и правого предсердия (ПП). Косвенные признаки гипертрофии левого (ЛЖ) и правого желудочка (ПЖ). Ненарастание зубца $R$ в отведениях
$\mathrm{V}_{1}, \mathrm{~V}_{2}, \mathrm{~V}_{3}$. Изменения процессов реполяризации в области переднебоковой стенки ЛЖ (-), зубцы $T$ в отведениях I, avL и (-+) $\mathrm{V}_{5-6}$; рис. 1.

Данные ЭхоКГ представлены в табл. 1 и на рис. 2-5.

Как представлено в табл. 1 и на рис. 2, при ЭхоКГ-исследовании обнаружено:

- гипертрофия миокарда ЛЖ и ПЖ, индекс массы миокарда ЛЖ 261 г/м², толщина межжелудочковой перегородки (МЖП) 24 мм, толщина задней стенки ЛЖ (ЗСЛЖ) $18 \mathrm{мм} \rightarrow 24$ мм, МЖП/ЗСЛЖ 1,33-1,0, что соответствует ГКМП-фенотипу. Размер полости ЛЖ не увеличен. Дилатация обоих предсердий (предсердно-желудочковое отношение 1,09-1,22), что соответствует осложненному ремоделированию, смешанный фенотип (ГКМП + рестриктивная кардиомиопатия - РКМП);

- прогрессирующая систолическая дисфункция ЛЖ (фракция выброса - ФВ ЛЖ: 47\% $\rightarrow 33 \% \rightarrow 28 \%$ ). МЖП обращена выпуклостью в сторону ЛЖ. Нарастание толщины передней стенки ПЖ - ПСПЖ (4 мм $\rightarrow 10$ мм $\rightarrow$ 11 мм). Расчетное систолическое давление в легочной артерии умеренно повышено (55-57 мм рт. ст.). Дилатация ПЖ. Выявлено небольшое количество свободной жидкости в полости перикарда; 

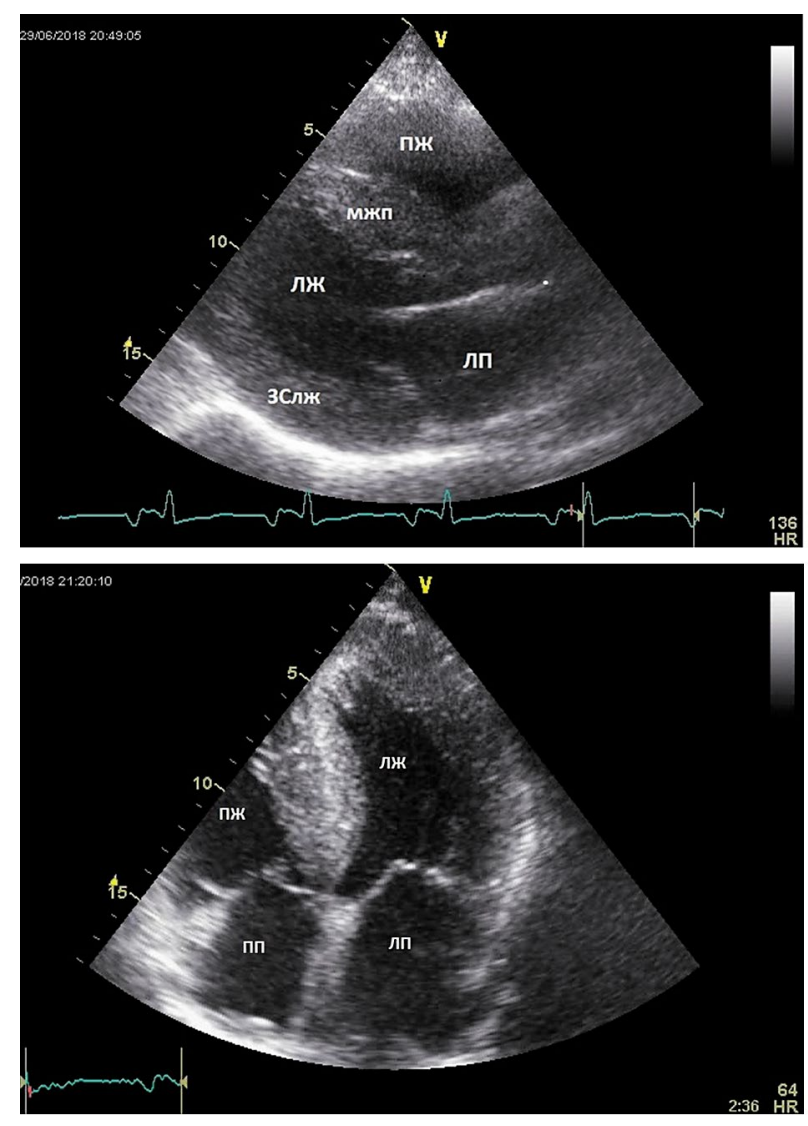

Рис. 2. ЭхоКГ пациента (парастернальная Алинная ось АЖ и апикамьное 4-камерное изображение).

- митральная и трикуспидальная регургитация 1-2 степени, незначительная приклапанная аортальная регургитация;

- выраженная диастолическая дисфункиия ЛЖ: рестриктивный тип наполнения ЛЖ (повышено конечно-диастолическое давление ЛЖ), Е/e'=35; максимальная скорость трикуспидальной регургитации 3,2 м/с (см. рис. 3, 4).

Резко снижена систолическая скорость движения кольца митрального клапана, низкие показатели деформации ЛЖ (средний 2D-strain $=-4,4 \%$, в большей степени нарушение кинетики задней, боковой и передней стенок ЛЖ, в меньшей степени снижены показатели деформации верхушки ЛЖ). Систолическая дисфункция ПЖ: TAPSE - 16 мм, TAVS - 7-8 см/с.

При суточном мониторировании ЭКГ:

- Синусовый ритм со средней частотой сердечных сокращений (ЧСС) 79 уд/мин (от 68 до 107).

- Желудочковая эктопическая активность 5 градации по Ryan в виде парных и групповых экстрасистол и пароксизмов желудочковой мономорфной тахикардии с ЧСС до 135 уд/мин общей длительностью 6 c.

- Наджелудочковая эктопическая активность в виде одиночных, парных и групповых экстрасистол, пароксизмов предсердной тахикардии, 1 эпизод комбинации желудочковых и наджелудочковых экстрасистол (4 комплекса). Зарегистрировано удлинение корригированного QT-интервала до 488 мс в течение 437 мин, что может являться прогностически неблагоприятным признаком у пациентов с сердечной недостаточностью.

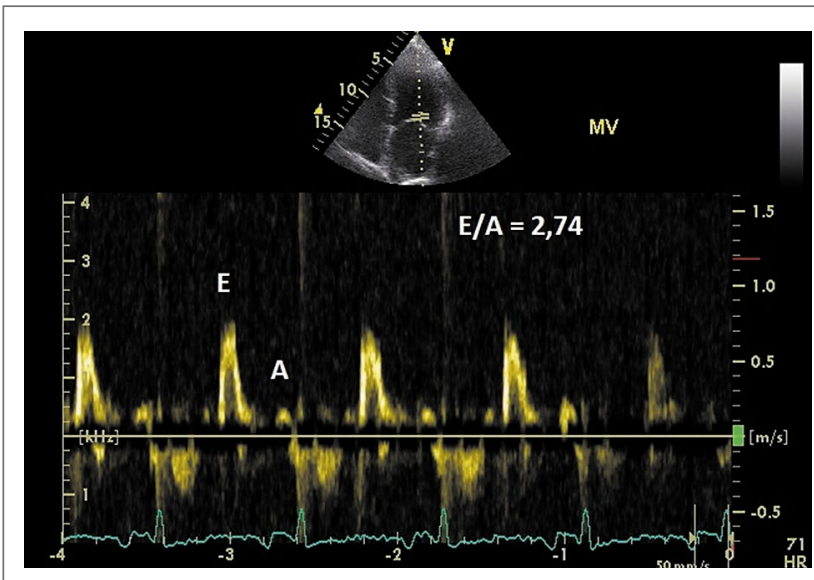

Рис. 3. Аопплерограмма трансмитрального кровотока ( $\mathrm{E}$ - скорость раннего напокнения $\Lambda Ж ; \mathrm{A}-$ скорость наполнения $\Lambda Ж$ в фазу систолы предсердий). Паттерн свидетельствует о рестриктивном типе наполнения $\Lambda Ж$ (E/A> 2), т.е. повышено Аавмение в $\Lambda$ П.

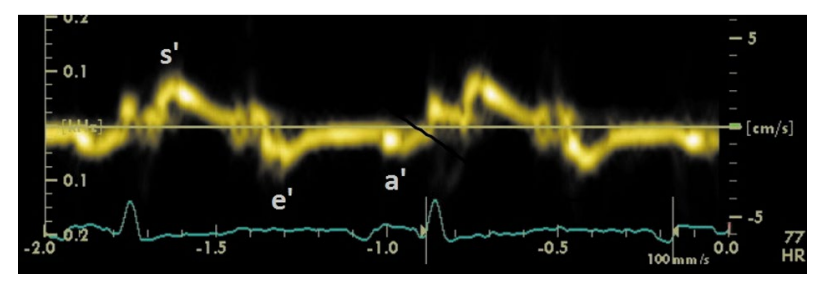

Рис. 4. Тканевая доппмерограмма матерамьной части митрального кольца (s', e', a' - скорости движения кольца митрального клапана в фазы систолы $\Lambda Ж$, раннего наполнения $\Lambda Ж$ и систолы предсердий соответственно).

- АВ-блокада 2-й степени 2-го типа (Мобитц 2), паузы 2,2 с, не сопровождавшиеся обмороком МорганьиЭдемса-Стокса (МЭС) (-).

Таким образом, у больного с длительным анамнезом корригируемой АГ и адекватной приверженностью терапии, ишемической болезнью сердца (ИБС), перенесшего ОКС, выявлены синдром быстропрогрессирующей бивентрикулярной ХСН, опасные для жизни желудочковые нарушения сердечного ритма и проводимости. Важно отметить наличие у пациента смешанного фенотипа ГКМП+РКМП, диастолической дисфункции ЛЖ (рестриктивный тип наполнения ЛЖ) и низковольтажной ЭКГ.

Дифференциальная диагностика проводилась между несемейной, необструктивной ГКМП и фенокопиями ГКМП, в первую очередь поражением сердца при различных формах амилоидоза.

Шаг №1. На основании анализа особенностей клинического течения заболевания, данных ЭКГ и трансторакальной ЭхоКГ можно сделать следующие выводы:

1. Прогрессирующая бивентрикулярная сердечная недостаточность с ФВ ЛЖ $<50 \%$ в отсутствие дилатационной фазы нетипична для ГКМП - болезни саркомера.

2. Прогрессирующее увеличение толщины ЗСЛЖ и ПСПЖ, смешанный фенотип (ГКМП+РКМП) характеризуют особенности ремоделирования сердца при инфильтративных заболеваниях миокарда и болезнях накопления. 


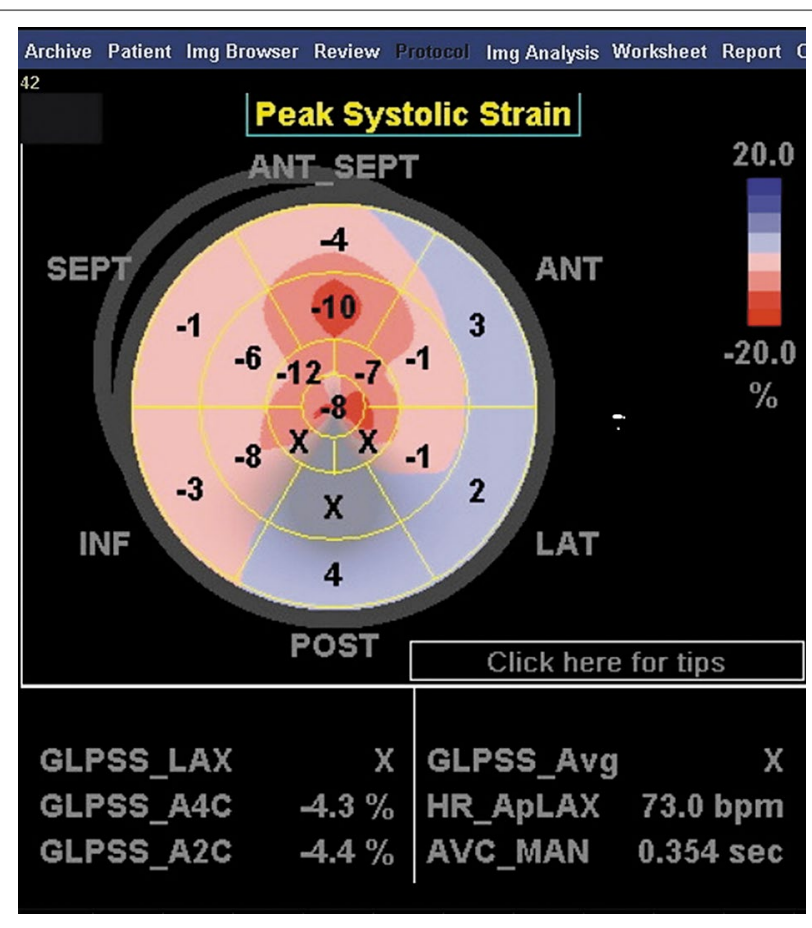

Рис. 5. Показатели продольной деформации на 17-сегментной схеме $\Lambda Ж$.

3. Комбинация 2 признаков - низкий вольтаж QRS на ЭКГ + увеличение толщины стенок ЛЖ $\geq 12$ мм по данным ЭхоКГ указывает на принадлежность пациента к когорте риска амилоидной кардиомиопатии (чувствительность 75\%, специфичность $67 \%$ ) $[4,5]$.

4. Для ГКМП не характерен паттерн деформации ЛЖ (2D-strain), выявленный у пациента при ЭхоКГ.

5. Для амилоидоза характерно снижение продольной деформации в базальных и срединных сегментах ЛЖ при относительной сохранности верхушки, что имеет место у данного пациента и представлено на рис. 5.

Значительное снижение продольной деформации, в большей степени задней, боковой и передней стенок ЛЖ. При ГКМП деформация снижена в максимально гипертрофированных сегментах, у пациента - в менее гипертрофированных.

Шаг №2. Для подтверждения амилоидоза «золотым стандартом» является биопсия клинически пораженного органа (сердце, почки). Однако в связи с инвазивностью процедуры в качестве альтернативы может использоваться биопсия подкожного жира передней брюшной стенки $[7,8]$.

Результаты морфологического исследования подкожно-жировой клетчатки представлены на рис. 6.

Вокруг микрососудов в стенке артерий имеют место гомогенные эозинофильные массы, окрашиваемые кон-

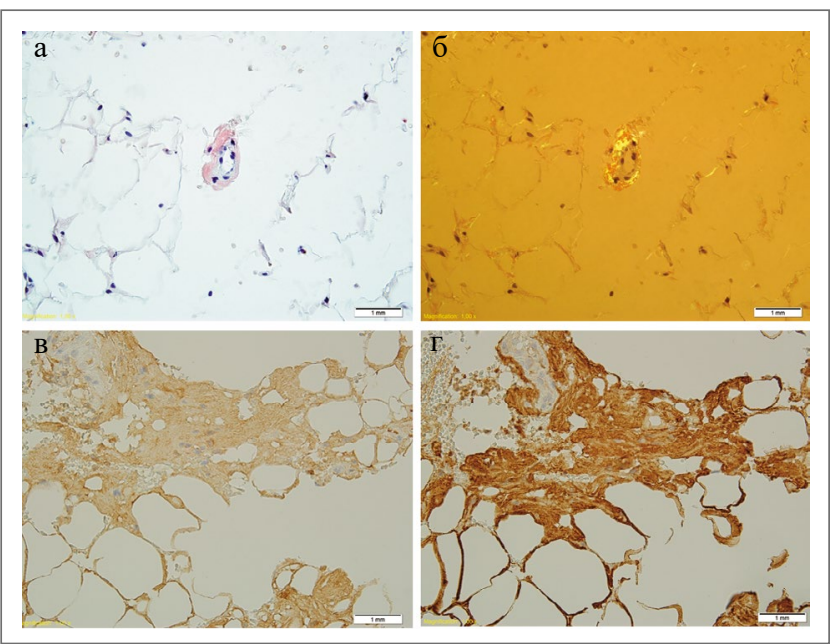

Рис. 6. Результаты морфологического исследования.

го-красным в красно-кирпичный цвет, в поляризованном свете - зеленое свечение (эффект двойного лучепреломления), что свидетельствует об отложении масс амилоида. При иммуногистохимическом исследовании обнаружена экспрессия лямбда-подтипа легких цепей иммуноглобулинов с рестрикцией каппа-цепи (см. рис. 6, $\boldsymbol{6}, \mathbf{2})$.

С целью исключения множественной миеломы проведено дополнительное обследование [9].

Амилоидогенный белок при AL-амилоидозе представляет собой легкую цепь иммуноглобулинов или фрагмент легкой цепи, который продуцируется клональной популяцией плазматических клеток в костном мозге или при моноклональной гаммапатии неопределенного значения (MGUS) или в связи с множественной миеломой (приблизительно у $10-15 \%$ пациентов). Соотношение каппа к лямбда варьируется от 0,26 до 1,65. Если этот показатель превышает 1,65, предполагается избыток каппа-цепей, а при соотношении менее 0,26 - избыток лямбда-цепей [6].

При постановке диагноза AL-амилоидоза обращают внимание на изменение лабораторных показателей, характеризующих плазмоклеточную дискразию:

- наличие моноклонального белка (иммуноглобулин/ легкая цепь) в сыворотке крови/моче, определяемого методом капиллярного электрофореза/иммунофиксации;

- повышение концентрации одной из свободных легких цепей иммуноглобулинов (вовлеченная цепь) в сыворотке крови и/или моче (нефелометрический метод, Freelite $^{\mathrm{TM}}$, Бирмингем, Великобритания) с нарушением их нормального соотношения $\kappa / \lambda$;

- увеличение количества плазматичесих клеток в миелограмме (обычно от 5 до 10\% по данным аспирационной биопсии).

Оценка уровня свободных легких цепей иммуноглобулинов каппа и лямбда в сыворотке крови и моче подтвердила

\section{Таблица 2. Результаты определения свободных ^егких цепей иммуноглобулинов в сыворотке крови и моче}

\begin{tabular}{|c|c|}
\hline $\begin{array}{l}\text { Свободные легкие цепи каппа и лямбда-цепи } \\
\text { иммуноглобулинов в сыворотке крови }\end{array}$ & $\begin{array}{c}\text { Свободные легкие цепи каппа и лямбда-цепи } \\
\text { иммуноглобулинов в моче }\end{array}$ \\
\hline Каппа-цепи 4,52 мкг/мл $(3,25-15,81)$ & Каппа-цепи 0,44 мкг/мл $(0,4-20)$ \\
\hline Лямбда-цепи 342,70 мкг/мл $(3,23-28,05)$ & Лямбда-цепи 0,12 мкг/мл $(0,3-5,0)$ \\
\hline
\end{tabular}




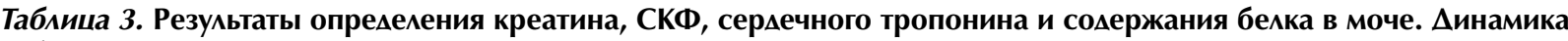
лабораторных показателей

\begin{tabular}{lcccc}
\hline & $\mathbf{1 7 . 1 1 . 2 0 1 8}$ & $\mathbf{2 0 . 1 1 . 2 0 1 8}$ & $\mathbf{2 1 . 1 1 . 2 0 1 8}$ & $\mathbf{2 7 . 1 1 . 2 0 1 8}$ \\
\hline Креатинин, мкмоль/л & 109,0 & 96,0 & 91,0 & - \\
СКФ (СКD-ЕРІ), мл/мин/1,73 м² & 63 & 74 & 79 & - \\
Протеинурия (по ОАМ), г/л & 0,10 & - & 0,25 & 0,60 \\
Сердечный тропонин, нг/мл & 0,26 & 0,33 & 141,2 & 151,0 \\
Гемоглобин, г/л & 151,7 & 148,6 & - \\
NТ-ргоВNР, пг/мл & 2500 & - & - \\
\hline
\end{tabular}

повышенное содержание легких цепей лямбда как основу для формирования амилоида (табл. 2).

Повышенный уровень легких цепей лямбда в сочетании с уровнем тропонина и натрийуретического пептида позволяет отнести пациента к группе высокого прогностического риска (табл. 3). Изменений в общем анализе мочи (OAM) не выявлено. Уровень креатинина 107,6 мкмоль/л, суточная микроальбуминурия 2,4 мг/сут. Скорость клубочковой фильтрации (СКФ) незначительно снижена - 64 мл/мин/1,73 м² (CKD-EPI), что свидетельствует о хронической болезни почек C2A1, которую можно объяснить наличием у пациента гипертонической болезни и сахарного диабета, хронического пиелонефрита. Не получено данных в пользу поражения печени и других органов амилоидозом.

По данным миелограммы (аспирационная биопсия костного мозга) количество плазматических клеток в костном мозге не превышало $10 \%$ (6,3\%).

У пациента отсутствовали типичные внесердечные проявления системного амилоидоза, такие как: периорбитальная пурпура (15\%), макроглоссия (отмечается у 9-20\% больных), ногтевая дистрофия, туннельный карпальный синдром (отмечается у 21\% больных) и др. [1]. Не складывается впечатления о поражении почек как критерия CRAB [9].

$\mathrm{C}$ целью исключения поражения костей при множественной миеломе проведена комбинированная позитронно-эмиссионная и рентгеновская компьютерная томография всего тела с фтордезоксиглюкозой: признаков костного деструктивного синдрома, а также патологического накопления радиофармпрепарата (РФП) в зоне исследования не выявлено. Аденопатия лимфоузлов средостения с низкой метаболической активностью. Уровень ионизированного Са - 1,17 ммоль/л в пределах референтных значений $(1,16-1,32$ ммоль/л).

Таким образом, данных в пользу множественной миеломы не получено. При этом значительное повышение уровня одной из легких цепей иммуноглобулинов (лямбда), а также ее доминирование при иммуногистохимическом исследовании биоптата подкожного жира передней брюшной стенки свидетельствует о развитии у пациента AL-амилоидоза. Подозрение на вовлечение в патологический процесс сердца сформулировано на основании особенностей клинического течения и анализа ЭКГ, ЭхоКГ, тканевой допплерографии.

Шаг №3. Важность своевременной постановки этиологического диагноза амилоидоза (AL vs ATTR) определяется принципиально разными подходами к терапии, тем более что в настоящее время существует ряд новых эффективных препаратов для лечения и того, и другого типа амилоидоза $[10,11]$. При секвенировании гена транстиретина мутаций не обнаружено.

Согласно рекомендациям Европейского общества кардиологов (2014 г.) по ГКМП для пациентов, имеющих симптомы, признаки и неинвазивные маркеры амилоидоза рекомендовано проведение остеосцинтиграфии (ОСГ) с бисфосфонатами.

ОСГ позволяет дифференцировать AL- и TT-амилоидоз по интенсивности поглощения миокардом РФП ( ${ }^{99 \mathrm{~m}} \mathrm{Tc}-п и-$ рофосфат и ${ }^{99 \mathrm{~m}} \mathrm{Tc}-\mathrm{DPD}$; класс IIa, уровень доказательности В) [12]. Более выраженный захват РФП наблюдается при ТTР-амилоидозе, более слабый - при AL-амилоидозе. Кроме того показано, что при неамилоидных формах кардиомиопатий захват РФП миокардом отсутствует [13-15].

Проведена статическая полипозиционная ОСГ с 99m Тс-фосфотех (этидроновая кислота; «НПО Диамед», Москва) костей скелета в режиме «все тело» - очаги патологической фиксации РФП у пациента не выявлены. В проекции миокарда ЛЖ определяется среднеинтенсивное накопление РФП, что может свидетельствовать о наличии амилоидных отложений в миокарде (рис. $7, \boldsymbol{a})$.

Для сравнения приведены данные статической полипозиционной сцинтиграфии костей скелета в режиме «все тело» больного 60 лет с доказанным ATTR-амилоидозом, опубликованные нами ранее [16]. Индекс сердце/контрлатеральная область $>1,5$ характерен для транстиретинового амилоидоза, соответственно $<1,5$ - для AL-амилоидоза, что продемонстрировано на рис. 7 .

Таким образом, результаты обследования больного свидетельствуют в пользу диагноза:

$A L$-амилоидоз с преимущественным поражением сердия.

Сопутствующая патология: ИБС: стенокардия напряжения II функиионального класса (ФК). ОКС (2018 г.). КАГ со стентированием ОА и ПМЖА. Гипертоническая болезнь III стадии, риск сердечно-сосудистых осложнений 4.

Осложнения: ХСН ІІІ ФК, 26 стадия. АВ-блокада 2-й степени 2-го типа (Мобити 2). Желудочковые нарушения сердечного ритма V градации по Lown, МЭС (-).

Важность отбора пациентов с AL-амилоидозом для проведения этиопатогенетического лечения диктуется более высоким уровнем посттрансплантационной смертности по сравнению с пациентами с миеломой (до 12-40\% против 5\% по данным различных авторов). Необходимо соблюдать баланс между эффективностью выбранного режима и способностью пациента перенести его токсичность [17-20]. 


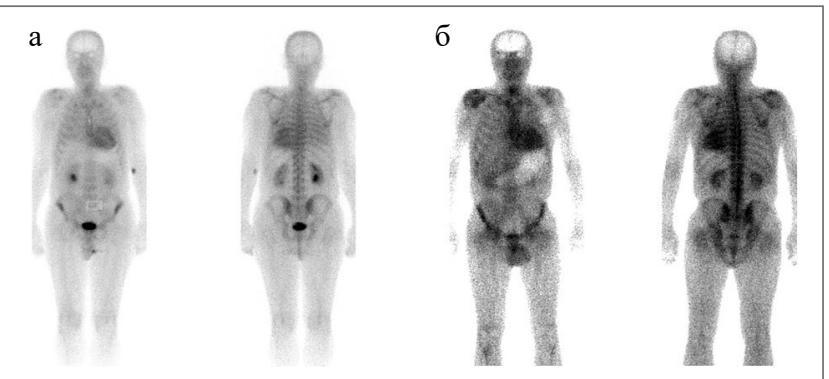

Рис. 7. Результаты ОСГ пациента: изолированный кардиальный AL-амимоидоз (a) и при генетически обусловленном не-V30M-транстиретиновом амимоидозе (б); больной с AL-амимоидозом с преимущественным поражением сердца; а - коэффициент Аифференциального накопления $1: 1,43) ; 6$ - больной с не-V30M ATTR с преимущественным поражением сердца. Коэфффициент диффференциального накопления 1:1,99 [8, 9].

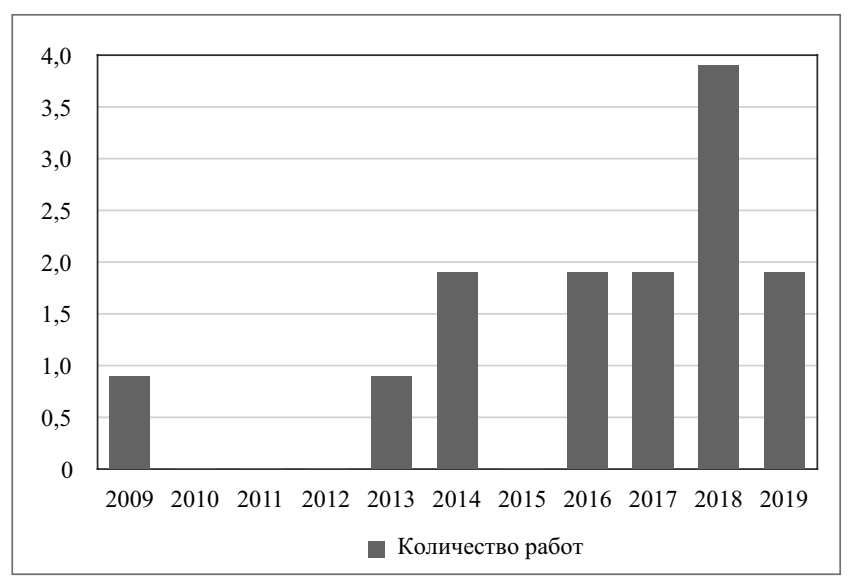

Рис. 8. Количество описанных кАинических случаев поражения сердца при AL-амимоидозе в России по данным E-library за последние 10 мет.

S. Kumar и соавт. (2012 г.) показана прогностическая значимость еще одного показателя - разности между вовлеченными и невовлеченными легкими цепями (dFLC $\geq 180$ мг/л) [21], на основании чего создана и валидирована новая прогностическая модель, где каждый показатель оценивается в 1 балл: cTnT $\geq 0,025$ нг/мл, мозговой натрийуретический пептид (NT-proBNP) $\geq 1800$ пг/мл, dFLC $\geq 180$ мг/дл [21].

Выделено 4 стадии (I, II, III, IV) в зависимости от количества баллов (табл. $4, \mathbf{5})$.

К определяющим критериям относятся: физиологический возраст менее 70 лет (паџиенту 59 лет), общесоматический статус $\mathrm{XCH} \leq \mathrm{II}$ ФК (шкала Нью-Йоркской ассоциации сердца - NYHA), у паџиента тяжесть ХCH на фоне проводимой терапии соответствует III ФК (NYHA), уровень сердечного тропонина T $<0,06$ нг/мл (уровень сердечного тропонина варьируется от 0,24 до 0,6 нг/ мл), систолическое АД более 90 мм рт. ст. (у пациента АД 120-110/80), клиренс креатинина $\geq 30$ мл/мин/1,73 м² (y паичента СКФ - CKD-EPI - варьируется от 63 до 79 мл/мин/1,73 $\mathrm{M}^{2}$ ), а также менее чем 3 органа значительного поражения [22]. Наилучшие результаты достигаются у пациентов группы низкого риска [21], к которым относятся 15-20\% пациентов [23]. Пациент не относится к группе низкого риска, которым показана аутологичная трансплантация стволовых периферических клеток крови. Ожида-
Таблица 4. Баммьный метох оценки мабораторных показатекей

\begin{tabular}{lc}
\hline Характеристика & Баллы \\
\hline $\begin{array}{l}\text { Разница между вовлеченными } \\
\text { и невовлеченными свободными } \\
\text { легкими цепями иммуноглобулинов } \\
\text { (dFLC) } \geq 180 \text { мг/л }\end{array}$ \\
$\begin{array}{l}\text { Сердечный тропонин (cTnT) }>0,025 \\
\text { NT-proBNP }>1800 \text { пг/мл }\end{array}$ \\
\hline
\end{tabular}

Таблица 5. Стации AL-амимоицоза и медиана выживаемости (ахаптировано [21])

\begin{tabular}{lccc}
\hline Стадия & Баллы & \% пациентов & $\begin{array}{c}\text { Медиана } \\
\text { общей выжи- } \\
\text { ваемости, мес }\end{array}$ \\
\hline I (0 баллов) & 0 & 25 & 94,1 \\
II (1 балл) & 1 & 27 & 40,3 \\
III (2 балла) & 2 & 25 & 14 \\
IV (3 балла) & 3 & 23 & 5,8 \\
\hline
\end{tabular}

емая медиана продолжительности жизни нашего пациента составляет 5,8 мес. Для сравнения, по данным S. Dubrey и соавт., медиана выживаемости пациентов после постановки диагноза в среднем составляла 1,08 года $(0,83-1,25)$ [5]. Наш пациент относится к пациентам высокого риска (IV стадия).

Несмотря на высокий риск неблагоприятного исхода, принято решение о проведении терапии, однако до начала терапии наступила внезапная сердечная смерть (ВСC).

\section{Закмючение}

Изолированное/преимущественное поражение сердца амилоидозом до настоящего времени остается недоцененной причиной ХСН. Диагноз амилоидоза сердца должен быть исключен у всех пациентов с быстропрогрессирующей сердечной недостаточностью с изначальной сохранной далее сниженной ФВ ЛЖ, ассоциированной с осложненным ремоделированием (ГКМП+РКМП). По нашим данным и исследованиям других авторов показано, что до верификации диагноза больные наблюдаются под кодами других заболеваний (ИБС, миоперикардит, различные идиопатические кардиомиопатии), обращаются к пяти и более врачам $[24,25]$. За последние 10 лет отмечается рост публикаций, посвященных описанию отдельных пациентов с амилоидной кардиомиопатией (рис. 8).

Практически все авторы описывают клинический статус пациента с амилоидной кардиомиопатией на далеко зашедшей стадии заболевания [26-29] либо случаи посмертной диагностики AL-амилоидоза с преимущественным поражением сердца [30, 31].

В работе В.В. Рамеева и соавт. (2019 г.) показано, что у пациентов c AL-амилоидозом наиболее неблагоприятное влияние на течение заболевания и риск летального исхода оказывали ХCH и ортостатическая гипотензия, а также основные структурно-функциональные параметры миокарда: толщина миокарда $>14$ мм, рестриктивный тип наполнения 


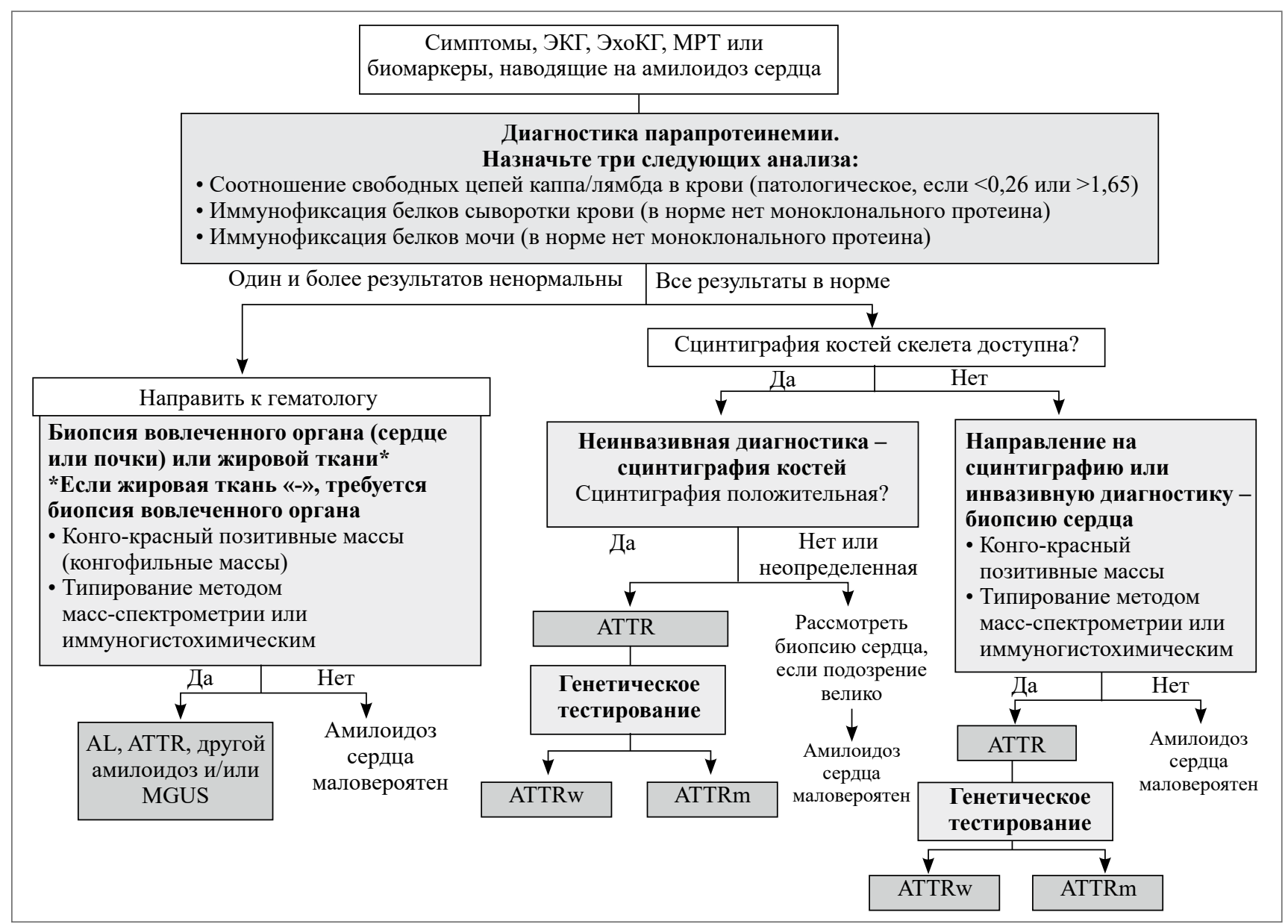

Рис. 9. Амгоритм выявления амимоидных кардиомиопатий (аАаптировано [33]).

Примечание. МРТ - магнитно-резонансная томография.

ЛЖ, снижение сократимости миокарда [32]. По нашим данным [25, 31] и сведениям литературы [32], наиболее агрессивные темпы прогрессирования неблагоприятного варианта ремоделирования (англ. adverse remodeling) характерны для поражения сердца при AL-амилоидозе.

Согласно рекомендациям экспертов (2019 г.) серьезным вызовом для клиницистов является создание алгоритма действий врача, которые приведут к выявлению амилоидных кардиомиопатий при транстиретиновом (mt wt) и AL-aмилоидозе на более ранних сроках (рис. 9).

В первую очередь это относится к случаям «изолированного/преимущественного» поражения сердца амилоидозом. При AL-амилоидозе промежуток времени между выявлением «беспричинной гипертрофии ЛЖ» и продвинутой стадией заболевания, характеризующейся смешанным фенотипом (ГКМП+РКМП), тяжелой сердечной недостаточностью, опасными для жизни желудочковыми нарушения ритма и проводимости, так называемое «окно возможностей», может составлять от 3 до 6 мес. Без лечения от появления первых симптомов поражения сердца (часто недиагностируемых) до летального исхода при AL-амилоидозе проходит от 6-12 мес. Риск BCC увеличивается в зависимости от стадии заболевания. Имплантация кардиовертера-дефибриллятора пациентам с амилоидозом сердца менее эффективна, и влияние на долгосрочный прогноз, в отличие от ГКМП - болезни саркомера, не доказано [34]. Описаны случаи электромеханической диссоциации как причины ВСС при амилоидных кардиомиопатиях у пациентов с имплантированным кардиовертером-дефибриллятором [35]. Наличие у нашего пациента коронарной болезни сердца являлось дополнительным негативным фактором, утяжеляющим течение и прогноз заболевания. Необходимо учитывать, что при AL-амилоидозе с поражением сердца возможно также наличие выраженной ишемии миокарда и инфаркта миокарда, обусловленных обструктивным поражением интрамуральных коронарных артерий [36]. Набор фармакологических препаратов ограничен мочегонными. $\beta$-Адреноблокаторы не рекомендуются для долгосрочной терапии и могут усугубить симптоматику из-за относительно быстрого развития проаритмогенных побочных эффектов и прогрессирования ХСН. Из-за выраженного увеличения жесткости ЛЖ резерв увеличения ударного объема (УО) при нагрузке крайне мал, поэтому сердечный выброс при амилоидозе зависит от ЧСС. Снижение ЧСС на фоне терапии $\beta$-адреноблокаторами приводит к снижению сердечного выброса и нарастанию $\mathrm{XCH}[36,37]$. Внезапная сердечная смерть и застойная сердечная недостаточность являются наиболее частыми причинами смерти.

Однако при ранней диагностике современная медицина в состоянии помочь и продлить жизнь пациентам на годы.

Каждый шаг в патогенезе AL-амилоидоза, начиная от продукции белка-предшественника и заканчивая формированием амилоидных отложений, может быть точкой 
приложения для терапии. На протяжении последних десятилетий основной целью терапии является подавление клональной продукции легких цепей иммуноглобулинов плазматическими клетками, являющимися субстратом для формирования данного вида амилоидоза. С этой целью для лечения множественной миеломы. Наиболее эффективными признаны химиотерапевтические режимы на основе протеосомного ингибитора І поколения бортезомиба (комбинации с глюкокортикостероидами, Циклофосфаном/ мелфаланом) [17-20], позволяющие достигать гематологического ответа у 24-65\% больных, что может способствовать снижению темпов прогрессии органных дисфункций [21]. Терапия на основе иммуномодулирующего препарата леналидомид не продемонстрировала высокой эффективности (гематологический ответ у $8-25 \%$ больных). Важно отметить необходимость проведения высокодозной химиотерапии мелфаланом в дозе 140-200 мг/м² с последующей аутологичной трансплантацией стволовых периферических клеток крови в 1-й линии терапии у пациентов, удовлетворяющих критериям возможности проведения данной процедуры [22]. Важность отбора пациентов диктуется более высоким уровнем посттрансплантационной смертности по могут быть использованы препараты, зарегистрированные

сравнению с пациентами с миеломой (до 12-40\% против 5\% по данным различных авторов) [23].

Внедрение ОСГ в кардиологическую клиническую практику существенно увеличивает возможности неинвазивной диагностики поражения сердца различными формами амилоидоза. Возможно, это позволит сократить время до постановки диагноза, способствовать своевременному началу этиопатогенетического лечения и, следовательно, сделать первые шаги к улучшению прогноза.

Работа выполнена в рамках Государственного задания Минздрава России по теме: "Молекулярно-генетические предикторы и морфо-функииональные фенотипы сердечной недостаточности с сохраненной фракцией выброса левого желудочка при кардиомиопатиях различного генеза», № госрегистрачии АAAA-A18-118070690073-2.

The study is preformed within the Governmental Task force of the Ministry of Health of the Russian Federation "Molecular and genetic predictors and morphological and functional phenotypes of heart failure with preserved left ventricular ejection fraction in various cardiomyopathies" № AAAA-A18-118070690073-2.

Авторы заявляют об отсутствии конфликта интересов.

\section{Список сокрашений}

$\mathrm{AB}$ - атриовентрикулярный

АД - артериальное давление

ВCC - внезапная сердечная смерть

ГКМП - гипертрофическая кардиомиопатия

ЗСЛЖ - задняя стенка левого желудочка

ИБС - ишемическая болезнь сердца

КАГ - коронароангиография

ЛЖ - левый желудочек

ЛП - левое предсердие

МЖП - межжелудочковая перегородка

$\mathrm{OA} \mathrm{-} \mathrm{огибающая} \mathrm{артерия}$

ОКС - острый коронарный синдром

ОСГ - остеосцинтиграфия

ПЖ - правый желудочек

\section{МИTEPATYPA/REFERENCES}

1. WechalekarAD, Gillmore JD, Hawkins PN. Systemic amyloidosis. Lancet. 2016;387(10038):2641-54. doi: 10.1016/S0140-6736(15)01274-X

2. Sipe JD, Benson MD, Buxbaum JN, et al. Amyloid fibril proteins and amyloidosis: chemical identification and clinical classification International Society of Amyloidosis 2016 Nomenclature Guidelines. Amyloid. 2016;23(4):209-13. doi: 10.1080/13506129.2016.1257986

3. Skinner M, Sanchorawala V, Seldin DC, et al. High-Dose Melphalan and Autologous Stem-Cell Transplantation in Patients with AL Amyloidosis: An 8-Year Study. Ann Intern Med. 2004;140(2). doi: 10.7326/0003-4819-140-2-200401200-00008

4. Cacoub P, Axler O, De Zuttere D, et al. Amyloidosis and cardiac involvement. Ann Med Interne (Paris). 2000;151(8):611-7

5. Dubrey SW, Hawkins PN, Falk RH. Amyloid diseases of the heart: Assessment, diagnosis, and referral. Heart. 2011;97(1):75-84. doi: 10.1136/hrt.2009.190405

6. Ryšavá R. AL amyloidosis: advances in diagnostics and treatment. Nephrol Dial Transplant. 2019;34(9):1460-6. doi: 10.1093/ndt/gfy291

7. van Gameren II, Hazenberg BPC, Bijzet J, van Rijswijk MH. Diagnostic accuracy of subcutaneous abdominal fat tissue aspiration for detecting systemic amyloidosis and its utility in clinical practice. Arthritis Rheum. 2006;54(6):2015-21. doi: 10.1002/art.21902

8. Picken MM. Amyloidosis. Where are we now and where are we heading? Arch Pathol Lab Med. 2010;134(4):545-51. doi: 10.1043/1543-2165-134.4.545

9. Rajkumar SV, Dimopoulos MA, Palumbo A, et al. International Myeloma Working Group updated criteria for the diagnosis of multiple myeloma. Lancet Oncol. 2014;15(12):e538-48. doi: 10.1016/S1470-2045(14)70442-5
ПМЖА - передняя межжелудочковая артерия ПП - правое предсердие

ПСПЖ - передняя стенка правого желудочка

РКМП - рестриктивная кардиомиопатия

РФП - радиофармпрепарат

СКФ - скорость клубочковой фильтрации

ФВ - фракция выброса

ФК - функциональный класс

ФН - физическая нагрузка

$\mathrm{XCH}$ - хроническая сердечная недостаточность

ЧСС - частота сердечных сокращений

ЭКГ - электрокардиография

ЭхоКГ - эхокардиография

NT-proBNP - мозговой натрийуретический пептид
10. Adams D, Suhr OB, Hund E, et al. First European consensus for diagnosis, management, and treatment of transthyretin familial amyloid polyneuropathy. Curr Opin Neurol. 2016;29:S14-26. doi: 10.1097/WCO.0000000000000289

11. Dispenzieri A, Lacy MQ, Zeldenrust SR, et al. The activity of lenalidomide with or without dexamethasone in patients with primary systemic amyloidosis. Blood. 2007;109(2):465-70. doi: 10.1182/blood-2006-07-032987

12. Zamorano JL, Anastasakis A, Borger MA, et al. 2014 ESC guidelines on diagnosis and management of hypertrophic cardiomyopathy: The task force for the diagnosis and management of hypertrophic cardiomyopathy of the European Society of Cardiology (ESC). Eur Heart J. 2014;35(39):2733-79. doi: 10.1093/eurheartj/ehu284

13. Ryzhkova DV, Makurova TV, Kozlenok AV, Mitrofanova LB. Scintigraphic diagnosis of transthyretin cardiac amyloidosis (clinical case demonstration). Russ Electron J Radiol. 2017;7(1):117-22. doi: 10.21569/2222-7415-2017-7-1-117-122

14. Bokhari S, Castaño A, Pozniakoff T, et al. 99mTc-pyrophosphate scintigraphy for differentiating light-chain cardiac amyloidosis from the transthyretin-related familial and senile cardiac amyloidoses. Circ Cardiovasc Imaging. 2013;6(2):195-201. doi: 10.1161/CIRCIMAGING.112.000132

15. Gillmore JD, Maurer MS, Falk RH, et al. Nonbiopsy diagnosis of cardiac transthyretin amyloidosis. Circulation. 2016;133(24):2404-12. doi: 10.1161/CIRCULATIONAHA.116.021612

16. Гудкова А.Я., Полякова А.А., Амелин А.В., и др. Не val30met-транстиретиновая амилоидная кардиомиопатия. Обзор сведений 
литературы и клиническое наблюдение. Рос. кардиол. журн. 2018;2:21-128 [Gudkova AYa, Polyakova AA, Amelin AV, et al. NonVal30Met-transthyretin amyloid cardiomyopathy. Literature review and clinical case. Ros. kardiol. zhurn. 2018;2:21-128 (In Russ.)]. doi: 10.15829/1560-4071-2018-2-121-128

17. Kastritis E, Dimopoulos MA. Recent advances in the management of AL Amyloidosis. Br J Haematol. 2016;172(2):170-86. doi: 10.1111/bjh.13805

18. Sanchorawala V. Light-chain (AL) amyloidosis: diagnosis and treatment. Clin J Am Soc Nephrol. 2006;1(6):1331-41. doi: 10.2215/CJN.02740806

19. Reece DE, Hegenbart U, Sanchorawala V, et al. Long-term follow-up from a phase $1 / 2$ study of single-agent bortezomib in relapsed systemic AL amyloidosis. Blood. 2014;124(16):2498-506. doi: 10.1182/blood-2014-04-568329

20. Kastritis E, Wechalekar AD, Dimopoulos MA, et al. Bortezomib with or without dexamethasone in primary systemic (light chain) amyloidosis. J Clin Oncol. 2010;28(6):1031-7. doi: 10.1200/JCO.2009.23.8220

21. Kumar S, Dispenzieri A, Lacy MQ, et al. Revised prognostic staging system for light chain amyloidosis incorporating cardiac biomarkers and serum free light chain measurements. J Clin Oncol. 2012;30(9):989-95. doi: 10.1200/JCO.2011.38.5724

22. D'Souza A, Dispenzieri A, Wirk B, et al. Improved Outcomes After Autologous Hematopoietic Cell Transplantation for Light Chain Amyloidosis: A Center for International Blood and Marrow Transplant Research Study. J Clin Oncol. 2015;33(32):3741-9. doi: 10.1200/JCO.2015.62.4015

23. Sharpley FA, Petrie A, Mahmood S, et al. A 24-year experience of autologous stem cell transplantation for light chain amyloidosis patients in the United Kingdom. Br J Haematol. 2019;5187(5):642-52. doi: 10.1111/bjh. 16143

24. Lousada I, Comenzo RL, Landau H, Guthrie S, Merlini G. Light Chain Amyloidosis: Patient Experience Survey from the Amyloidosis Research Consortium. Adv Ther. 2015;32(10):920-8. doi: 10.1007/s12325-015-0250-0

25. Семернин Е., Полякова А., Крутиков А., и др. Системные формы амилоидоза в когорте пациентов с рефрактерной хронической сердечной недостаточностью в Санкт-Петербурге. Редкие орфанные заболевания и врожденные пороки развития. Современные возможности диагностики, профилактики, лечения и реабилитации. СПб., 2014; с. 204-18 [Semernin E, Polyakova A, Krutikov A, et al. Sistemnye formy amiloidoza $v$ kogorte patsientov s refrakternoi khronicheskoi serdechnoi nedostatochnost'yu v Sankt-Peterburge. Redkie orfannye zabolevaniya i vrozhdennye poroki razvitiya. Sovremennye vozmozhnosti diagnostiki, profilaktiki, lecheniya reabilitatsii. Sankt-Peterburg, 2014; p. 204-18 (In Russ.)].

26. Загребнева А.И., Потешкина Н.Г., Кузнеченко Д.И., Бабак В.В. Системный амилоидоз, ассоциированный с множественной миеломой: клиническое наблюдение. РМЖ. 2018;12(II):107-9 [Zagrebneva AI, Poteshkina NG, Kuznechenko DI, Babak VV. Sistemnyi amiloidoz, assotsiirovannyi s mnozhestvennoi mielomoi: klinicheskoe nablyudenie. RMZh. 2018;12(II):107-9 (In Russ.)].

27. Назипова 3.М., Халиуллина Л.Р., Ахмадеев А.Р., и др. Клинический случай AL-амилоидоза. Практ. медищина. 2017;8(109):99-101 [Nazipova ZM, Khaliullina LR, Akhmadeev AR, et al. Clinical case of AL-type amyloidosis. Prakt. meditsina. 2017;8(109):99-101 (In Russ.)].

28. Галеева 3.М., Галявич А.С., Балеева Л.В., и др. Случай амилоидоза в кардиологической практике. Кардиология. 2019;59(1):93-6 [Galeeva ZM, Galyavich AS, Baleeva LV, et al. The Case of Amyloidosis in Cardiological Practice. Kardiologiya. 2019;59(1):93-6 (In Russ.)]. doi: $10.18087 /$ cardio.2019.1.10221

29. Смирнова Е.А. Филоненко С.П. Хроническая сердечная недостаточность у больной с системным амилоидозом, ассоциированным с множественной миеломой (клиническое наблюдение). Сердечная недостаточность. 2016;11(5):376-80 [Smirnova EA. Filonenko SP. Chronic heart failure in a female patient with systemic amyloidosis associated with multiple myeloma (case report). Serdechnaya nedostatochnost'. 2016;11(5):376-80 (In Russ.)]. doi: 10.18087/rhfj.2016.5.2253

30. Пашковкина О.В., Путинцев В.А., Богомолов Д.В., и др. Случай посмертной диагностики плазмоцитомы и системного AL-амилоидоза с преимущественным поражением сердца. Литературная справка. Кремлевская медицина. Клин. вестник. 2018;4(2):2-61 [Pashkovkina OV Putintsev VA, Bogomolov DV, et al. The case of post-mortem diagnosis of plasmacytoma and systemic AL-amyloidosis with primary cardiac involvement. Literary references. Kremlevskaya meditsina. Klin. vestnik 2018;4(2):52-61 (In Russ.)]. doi: 10.26269/9hyn-vw44

31. Рыбакова М.Г., Семернин Е.Н., Кузнецова И.А., Гудкова А.Я. Кардиальные проявления амилоидоза. Архив патологии. 2009;71(2):3-7 [Rybakova MT, Semernin EN, Gudkova AYa, Kuznetsova IA. Cardiac manifestations of amyloidosis. Arkhiv patologii. 2009;71(2):3-7 (In Russ.)].

32. Рамеев В.В., Козловская Л.В., Рамеева А.С., и др. Особенности эволюции и прогностическое значение поражения сердца у больных системным AL-амилоидозом. Клин. фармакология и терапия. 2019;28(2):49-56 [Rameev VV, Kozlovskaya LV, Rameeva AS, e al Evolution and prognostic significance of heart involvement in patients with systemic AL-amyloidosis. Klin. farmakologiia i terrapiia. 2019;28(2):49-56 (In Russ.)]. doi: 10.32756/ 0869-5490-2019-2-49-56

33. Maurer MS, Bokhari S, Damy T, et al. Expert Consensus Recommendations for the Suspicion and Diagnosis of Transthyretin Cardiac Amyloidosis. Circ Heart Fail. 2019;12(9):e006075. doi: 10.1161/CIRCHEARTFAILURE.119.006075

34. Banypersad SM, Moon JC, Whelan C, et al. Updates in cardiac amyloidosis: A review. $J$ Am Heart Assoc. 2012;1(2). doi: 10.1161/JAHA.111.000364

35. Grogan M, Dispenzieri A. Natural history and therapy of AL cardiac amyloidosis. Heart Fail Rev. 2015;20(2):155-62. doi: 10.1007/s10741-014-9464-5

36. Tsai SB, Seldin DC, Wu H, et al. Myocardial infarction with "clean coronaries" caused by amyloid light-chain AL amyloidosis: a case report and literature review. Amyloid. 2011;18(3):160-4 doi: $10.3109 / 13506129.2011 .571319$

37. Семернин Е.Н., Баранова Е.И., Кузнецова И.А., и др. Под ред. Е.В. Шляхто. Алгоритмы диагностики и врачебная тактика при поражении сердечно-сосудистой системы различными формами амилоидоза. Пособие для врачей. СПб.: Изд-во СПбГМУ, 2009; с. 95 [Semernin EN, Baranova EI, Kuznetsova IA, et al. Ed. E.V. Shlyakhto Algoritmy diagnostiki i vrachebnaya taktika pri porazhenii serdechnososudistoi sistemy razlichnymi formami amiloidoza. Posobie dlya vrachei. Saint Petersburg: Izdatel'stvo SPbGMU, 2009; p. 95 (In Russ.)].

Статья поступила в редакцию / The article received: 16.01.2020

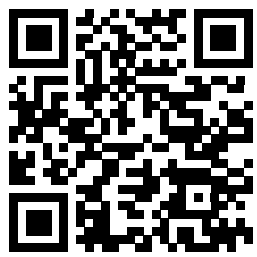

OMNIDOCTOR.RU 